\title{
Building energy efficiency policies and practices in Pakistan: A literature review
}

\author{
Waqas Ahmed Mahar, ${ }^{\mathrm{a}, \mathrm{b}}$; ; Naveed Ur Rehman Anwar ${ }^{\mathrm{a}}$; Shady Attia ${ }^{\mathrm{b}}$ \\ ${ }^{a}$ Department of Architecture, Balochistan University of Information Technology, Engineering \& Management Sciences (BUITEMS) \\ Quetta, Pakistan \\ ${ }^{\mathrm{b}}$ Sustainable Building Design (SBD) Lab, Deptt. of UEE, Faculty of Applied Sciences, Universitè de Liège, Belgium
}

\begin{abstract}
The household sector in Pakistan became the largest consumer of electricity which is responsible for more than 51\% of the national consumption. The Building Energy Code of Pakistan was developed in 1990, yet the institutional setup regarding energy efficiency \& conservation is inadequate. There is lack of experts and implementation of policies at national and provincial level. The study aims to explore the energy efficiency and conservation policies in Pakistan and their impact on reducing household energy consumption. The issues related to the implementation of policies across the country have been further discussed. The paper provides an overview of the energy sector and its challenges related to residential buildings. Energy policies, standards and literature related to building sector were analyzed and discussed with the experts. Moreover, suggestions and recommendations are made for the possible solutions and improvement of the existing situation.
\end{abstract}

(C) 2018 Waqas Ahmed Mahar, ${ }^{\mathrm{a}, \mathrm{b},{ }^{*}}$; Naveed Ur Rehman Anwar ${ }^{\mathrm{a}}$; Shady Attia ${ }^{\mathrm{b}}$. Selection and/or peer-review under responsibility of Energy and Environmental Engineering Research Group (EEERG), Mehran University of Engineering and Technology, Jamshoro, Pakistan.

Keywords: Energy; energy conservation; NEECA; building code; energy provisions

\section{Introduction}

Energy usage and demand is increasing globally at a high rate with the rapidly growing urban population, use of latest devices and technologies and expansion of users' net. Several countries around the globe are facing problems of energy shortage and increasing energy demand. Pakistan is also facing a serious energy crisis since last many years, where initially there was high rate of energy shortage; and now there are problems of energy supply and distribution and line losses. The country's population is growing at a rate of $2 \%$ per annum [1] while the urban population is growing at 3\% per annum which is highest in South Asia. United Nations Population Division estimated that by 2025 , nearly half of the country's population will live in urban areas [2].

In Pakistan, household sector became a major consumer of electricity by consuming $51 \%$ of the total national consumption between July '17-Feb'18. Figure. 1 presents the energy consumption by each sector [3]. In such a situation where there is energy shortage, problems of supply and demand, and household sector consumes the major part of the total electricity produced, there is a strong need to reduce the residential energy consumption by introducing energy conservation techniques and practices. Even there is awareness regarding energy consumption and climatic design yet a critical evaluation of the building stock in Pakistan would reveal that most of the current buildings are not designed by considering the climate conditions. The use of concrete and glass is common, and buildings do not provide required thermal comfort. Use of conditioning equipment is common feature in many of the buildings. It was found in recent studies that the majority of the houses in Quetta, Pakistan were constructed of concrete structure and single glazed glass was mainly used for glazing of windows and ventilators [4] [5]. 


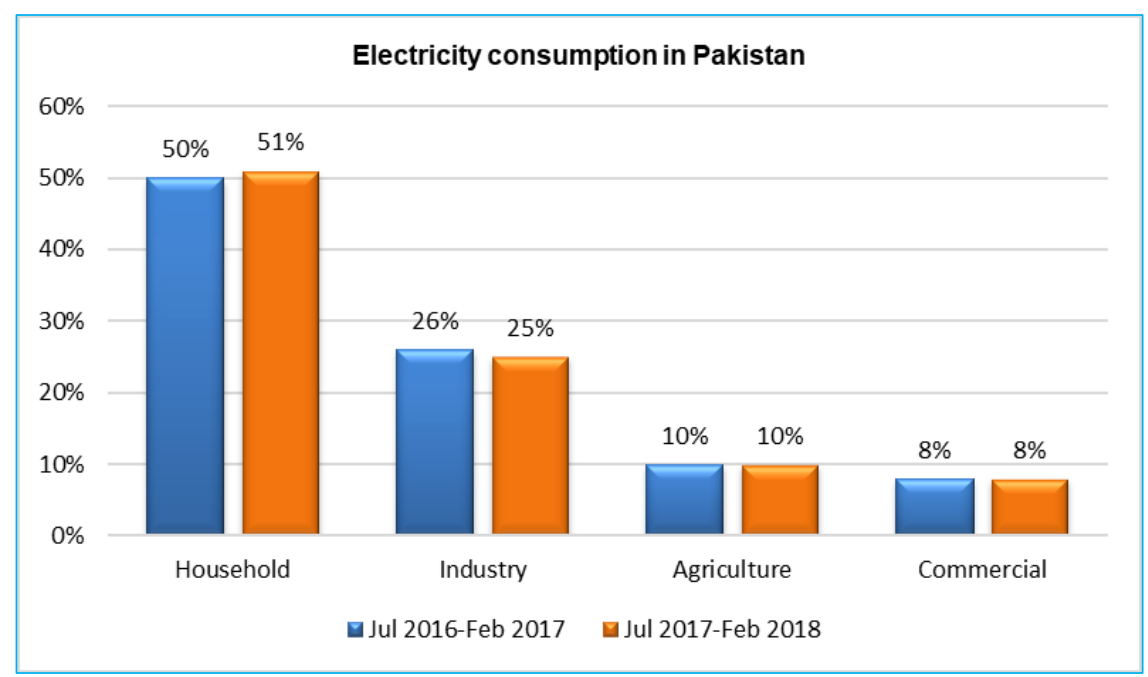

Figure 1. Electricity consumption in Pakistan

Source: Hydrocarbon Development Institute of Pakistan (HDIP), Ministry of Energy (Power Division)

At institutional level the efforts for energy conservation are unsatisfactory. There is one federal authority which is responsible for energy conservation in all sectors including buildings. The Building Energy Code of Pakistan (BECP) was developed in 1990 [6]. Since, there have been several technological developments in last 20 years which changed the lifestyle of the people and increased the energy consumption at domestic level. It became essential to revise and update this energy code to cater the recent developments. In 2011, Energy Provisions were developed to be included in the Building Code of Pakistan while in 2016 the federal government of Pakistan established, National Energy Efficiency \& Conservation Authority (NEECA), previously known as National Energy Conservation Centre (ENERCON). NEECA aims to introduce and implement energy conservation policies and practices in Pakistan. There are 4 provinces in Pakistan and 2 administrative units, namely Islamabad and Gilgit-Baltistan. So far at provincial level, only in Punjab province an authority was formed named as Punjab Energy Efficiency and Conservation Agency (PEECA) which aims to work together with NEECA for the energy efficiency and conservation in Punjab province. In rest of the provinces and administrative units of the country there is lack of such organizational and institutional setup. At individual level residents are trying to reduce their energy consumption by applying some techniques. NEECA also published guidelines and techniques which can help to reduce energy usage of residential buildings in Pakistan.

This study highlights the growing energy consumption needs of residential buildings in Pakistan. It further investigates the energy efficiency and conservation policies and practices, institutional setup and efforts taken at various levels for the energy efficiency and conservation in residential buildings in Pakistan. The first section of this paper presents introduction and identifies the research problem. Section 2 describes the methods used for this study, section 3 presents the existing policies, energy provisions and institutional setup regarding energy efficiency and conservation in Pakistan. Issues regarding housing, comfort, energy efficiency and renewable energy are presented in section 4 while conclusions are made in section 5 .

\section{Methodology}

The methodology for this study is based on the analysis of existing policies, policy documents and practices for the energy efficiency and conservation in residential buildings of Pakistan. It further focuses on the available literature and previous studies done in Pakistan or in the similar context. Various important factors influenced the housing sector and policies are explored. Discussion with the experts related to energy efficiency and conservation was made to formulate the results and the conclusion of this study. 
$5^{\text {th }}$ International Conference on Energy, Environment \& Sustainable Development (EESD) 2018

Mehran University of Engineering \& Technology (MUET) Jamshoro, Pakistan

Author's Post Print

\section{Building Codes and institutional framework in Pakistan}

\subsection{Building Codes}

\subsubsection{Building Energy Code of Pakistan (BECP)}

Building Energy Code of Pakistan was developed in 1990 by National Energy Conservation Centre (ENERCON). The code provides minimum performance standards for buildings, windows and openings, lighting and heating, ventilation and air-conditioning (HVAC). This code was an adopted version of ASHRAE standard 90.1. The whole country was divided into 5 climatic zones based on minimum and maximum recorded temperatures. The solar co-efficient, thermal conductance and other passive design standards and requirements are defined for each climatic zone. In 2008, a newer version of the BECP was introduced without any provision given for multifamily buildings of three or fewer stories above grade. The BECP focuses on commercial buildings and do not follow the guidelines of ASHRAE standard 90.2. A detailed analysis of household requirements in Pakistan together with the analysis of ASHRAE standard 90.2 is necessary to design the residential codes based on their specific needs. The analysis should also incorporate the climatic conditions and variations, passive design techniques and the use of local materials since in some parts of Pakistan the choice of materials used for building construction may vary and is only limited to locally available materials. For several years, the compliance with BECP was not mandatory. At later stages the poor planning strategy yielded ineffective results and enforcement of energy codes remained a challenge. In 2011, Building Code of Pakistan (Energy Provisions) were developed. In 2013, these energy provisions were promulgated into Building Code of Pakistan.

\subsubsection{Building Code of Pakistan (Energy Provisions-2011)}

With the changing life and technological advancements in last few decades, several household and personal equipment's were invented for domestic and personal use. Majority of these devices are operated on electricity or chargeable using electricity. Active cooling and heating systems got modified, changed and advanced. Mobile phones, internet and computers became an important part of our everyday life. On the other hand, electricity crisis in Pakistan hit the country affecting activities of daily life. Load-shedding or power-outage became regular in all seasons. Whereas, with the growing population and development the energy demand and usage also increased. This created a need to revise the building energy code as per the requirements of today's and future needs for energy conservation and minimizing energy consumption by improving efficiency in buildings. Energy Provisions-2011 made an integral part of Building Code of Pakistan and made compatible with the relevant standards of ASHRAE, ARI, ANSI, ASTM etc. Pakistan Engineering Council (PEC) is responsible for the development and implementation of the building codes and ENERCON as national coordinator for energy conservation measures and policies jointly worked to finalize the Energy Provisions-2011 to be included in Building Code of Pakistan.

The Building Code of Pakistan (Energy Provisions-2011), is mainly adopted from ASHRAE standard 90.1-2004. While its section-4, "Building Envelope" was developed based on the local environment and the Energy Codes of regional countries. The purpose of these provisions is to provide minimum requirements for the energy efficient design and construction of buildings [7]. The scope, application, exemptions and limitations of the provisions are summarized in Table 1.

The BCP (EP-2011) stresses on the compliance and enforcement of the code. It states that the review and approval of the plans and specification by respective sanctioning from the development authorities or municipalities shall be in accordance with the EP-2011. Administrative requirements related to the permit, standards, claim of exemptions, interpretations and the rights of appeal will be specified by the Authority Having Jurisdiction (AHJ) which can be the relevant development authority or municipal corporation. The BCP (EP-2011) further states that compliance documents must be submitted to show all pertinent data and features of the buildings, equipment and systems, in sufficient details to permit the AHJ to verify that building complies with the EP-2011. AHJ may also require supplementary information necessary for the verification of compliance with these provisions such as worksheets, calculations, compliance forms, manufacturer's literature etc. The mandatory requirements for the building systems are given in the EP-2011 which are mentioned in the Table 2. It is further mentioned that EP-2011 can be changed, updated or modified by PEC after minimum 3 years or maximum five years together with other stakeholders. 
$5^{\text {th }}$ International Conference on Energy, Environment \& Sustainable Development (EESD) 2018

Mehran University of Engineering \& Technology (MUET) Jamshoro, Pakistan

Author's Post Print

Table 1. The scope, application and limitations of BCP (EP-2011)

\begin{tabular}{|c|c|c|c|c|}
\hline \multicolumn{2}{|c|}{ Scope } & \multirow{2}{*}{ Building systems } & \multirow{2}{*}{ Exemptions } & \multirow{2}{*}{ Limitations } \\
\hline Load and area & Buildings & & & \\
\hline $\begin{array}{l}\text { It applies to buildings and } \\
\text { building clusters that have: } \\
\text {-A total connected load of } \\
100 \mathrm{~kW} \text { or higher } \\
\text {-Contract demand of } 125 \\
\mathrm{kVA} \text { or higher } \\
\text {-Conditioned area of } 900 \mathrm{~m}^{2} \\
\text { or greater } \\
\text {-Unconditioned buildings } \\
\text { with covered area of } 12,00 \\
\mathrm{~m}^{2} \text { or greater }\end{array}$ & $\begin{array}{l}\text { It is applicable to: } \\
\text {-New buildings and their } \\
\text { systems } \\
\text {-New portions of existing } \\
\text { buildings and their } \\
\text { systems if the connected } \\
\text { load exceeds the } \\
\text { mentioned limits } \\
\text {-Increase in electricity } \\
\text { load beyond the } \\
\text { mentioned limits }\end{array}$ & $\begin{array}{l}\text { Applicable building } \\
\text { systems: } \\
\text {-Building envelope } \\
\text {-Mechanical systems and } \\
\text { equipment including } \\
\text { HVAC } \\
\text {-Service water heating } \\
\text {-Lighting } \\
\text {-Electric power and motors }\end{array}$ & $\begin{array}{l}\text { Exempted buildings: } \\
\text {-Buildings that do not use } \\
\text { electricity or fossil fuel } \\
\text {-Government notified } \\
\text { heritage buildings } \\
\text {-Portion or equipment of } \\
\text { building systems that use } \\
\text { energy for manufacturing } \\
\text { process }\end{array}$ & $\begin{array}{l}\text {-In case of any conflict, } \\
\text { relevant provisions of } \\
\text { safety, health and } \\
\text { environment codes will } \\
\text { prevail }\end{array}$ \\
\hline
\end{tabular}

Table 2. Mandatory requirements for the building systems mentioned in BCP (EP-2011)

\begin{tabular}{|c|c|c|c|c|}
\hline Building Envelope & HVAC system & Service water heating & Lighting & $\begin{array}{c}\text { Electric power and } \\
\text { motors }\end{array}$ \\
\hline \multirow{7}{*}{$\begin{array}{l}\text {-External walls and roof } \\
\text {-Glass and framing } \\
\text {-Air leakages and } \\
\text { infiltration }\end{array}$} & -Temperature control & -Piping insulation & -Lighting controls & -Transformers \\
\hline & -Mechanical ventilation & -Equipment efficiency & -Exit signs & efficiency \\
\hline & \multirow{2}{*}{$\begin{array}{l}\text {-Piping and ducting work } \\
\text {-Air system balance }\end{array}$} & \multirow[t]{2}{*}{-Swimming Pools } & -Exterior building and & motors \\
\hline & & & ground lighting & $\begin{array}{l}\text {-Power } \\
\text { correction }\end{array}$ \\
\hline & \multirow{2}{*}{$\begin{array}{l}\text {-Voluntary adoptions } \\
\text { (natural ventilation, }\end{array}$} & & -Landscape lighting & \\
\hline & & & -Interior and exterior & -Check metering \\
\hline & alternate energy) & & lighting power & $\begin{array}{l}\text {-Power distribution } \\
\text { systems }\end{array}$ \\
\hline
\end{tabular}

\subsubsection{Building Code of Pakistan (BCP)}

Building Code of Pakistan is a document which contains necessary guidelines for the design, construction and safety of buildings. It was first published in 1986 by Ministry of Housing and Works, Government of Pakistan. BCP was used as a reference by engineers, however, it was not enforced as a mandatory requirement. The document is revised and updated by time to time to include new and improved studies, techniques and provisions approved by legislative bodies and stakeholders. PBC (EP-2011) were included in Building Code of Pakistan in 2013, in order to make this document more useful for building energy and conservation practitioners and to implement the energy efficiency and conservation policies across the country.

\subsection{Institutional framework}

For the development of policies, their adoption and implementation the relevant institutions and organizations play a vital role. A robust and effective institutional framework can only make a policy successful. Unfortunately, in many developing countries including Pakistan the institutional framework doesn't provide proper guidance, guidelines, expertise for the check and implementation of plans and policies and delivery of services at local and municipal level. The institutions at federal level are well- structured, compared to provincial and city level. This weak institutional setup lead to inefficient results of plans and policies. Considering the current topic this section will discuss relevant institutions responsible for the energy conservations policies and practices in Pakistan. 
$5^{\text {th }}$ International Conference on Energy, Environment \& Sustainable Development (EESD) 2018

Mehran University of Engineering \& Technology (MUET) Jamshoro, Pakistan

Author's Post Print

\subsubsection{Pakistan Engineering Council (PEC)}

Pakistan Engineering Council is a professional body and statutory federal institution established in 1976. PEC is responsible for the accreditation of engineering education, regulation of engineering profession in Pakistan and licensing and registration of engineers, engineering firms and consultants. PEC also assists federal and provincial governments and undertakes the efforts to establish scientific standards for engineering innovations and services in the country. For example, development of Building Code of Pakistan, its standards and its implementation and enforcement at various levels. PEC continuously adopts and changes the standards by time to time if needed to meet the current and future requirements of the industry.

\subsubsection{National Energy Efficiency and Conservation Authority (NEECA)}

In 2016, National Energy Conservation Centre (ENERCON) was transformed into National Energy Efficiency and Conservation Authority (NEECA). ENERCON was established in 1985 as USAID project and became an autonomous authority in 1986. After several changes it got the status of a fully functional authority in 2016. NEECA has following role and responsibilities:

- Preparing energy conservation programs for all major energy consumption sectors

- Development and introduction of energy conservation plans nation-wide

- Drafting policy guidelines to support energy conservation activities

- Development of a database on prospects for energy conservation

- Organizing and supporting training activities/ workshops on the application of energy conservation policies

- Carrying out field research and experimental studies on specific energy conservation technologies and procedures; and

- Implementation and monitoring of energy conservation programs by other public and private sector organizations

NEECA is continuously offering training and guidance for the knowledge exchange and implementation of its policies and practices. However, its overall performance is not very satisfactory to bring some considerable changes and enforcement of the policies.

\subsubsection{Punjab Energy Efficiency and Conservation Agency (PEECA)}

Punjab Energy Efficiency and Conservation Authority (PEECA) was established in 2016 to undertake the energy efficiency and conservation policies and practices in Punjab province of Pakistan. PEECA also carry out efforts for the demand side management of energy crisis, promotion of renewable energy and environmental protection. Several training programs and workshops have been organized by PEECA for the awareness of energy conservation. In 2017, PEECA also started a project for the solarization of public institutes in Punjab [8].

\subsubsection{Provincial, local authorities and municipal corporations}

For the effective implementation of any plan or policy, the provincial and local authorities or municipal corporation can play a vital role. Unfortunately, the local government system in Pakistan never remained effective due to political changes and reasons. It was altered several times; however, the federation or provinces kept their key role which weakened the system and made it ineffective. After $18^{\text {th }}$ amendment in the constitution of Pakistan, the provinces got more powers and autonomy. This made provinces responsible for several sectors including the local government system. However, the newly elected federal government is planning to introduce a new local government system in two provinces of Punjab and Khyber Pakhtunkhwa.

The concerned local authority or municipal corporation is mentioned as Authority Having Jurisdiction (AHJ) in the BCP (EP-2011). According to the law, these authorities are responsible for the planning permission, building bylaws, development at local level and the implementation of policies etc. As per the EP-2011, AHJ also need to make sure that all buildings must comply with the requirements of EP-2011. It is observed that many of these authorities or municipal corporation lack of technical and skilled staff who can understand the existing policies, proposals and can 
$5^{\text {th }}$ International Conference on Energy, Environment \& Sustainable Development (EESD) 2018

Mehran University of Engineering \& Technology (MUET) Jamshoro, Pakistan

Author's Post Print

play their role for the implementation. In almost every major city of Pakistan, there is a development authority. However, their role regarding urban planning and development remain unsatisfactory except of a few which managed to achieve targets and planned new strategies to cope with urban planning and housing issues.

\section{Key issues regarding housing, comfort and energy}

Considering the existing policies, plans and the institutional framework regarding housing and energy conservation sector, key problem of housing shortage in Pakistan is highlighted in this section. Moreover, significance of comfort, energy efficiency and conservation, and renewable energy is discussed. Other related issues which had impact on the overall situation are also mentioned in this section.

\subsection{Housing shortage}

Housing has great economic and social impact on human lives. It effects our lifestyle, health, environment, education and social life [9]. A faulty and defective house does not fulfil the demands and needs of the residents while a good house creates good living and working environment for the residents. Housing became a rapid growing industry due to technological advancement, increasing population and professional and skilled labour. Yet, housing sector is facing several challenges and problems including housing shortage, poor planning and design, improper services and facilities, unaffordability, housing finance, etc. [10]. Several countries including Pakistan are facing the problem of housing shortage which is increasing with the over growing population of the country. The estimated housing shortage in Pakistan is up to 10 million units [11] about 40 percent of which is in urban areas [12]. As per 1998 census the housing shortage was 4.3 million units, annual additional requirement was 0.57 million unit while the annual estimated production was 0.3 million units which was creating a recurring annual backlog of 0.27 million housing units [13]. In another study it was mentioned that annual housing demand in Pakistan was 0.6 million units while only 0.37 million units were being built annually and mostly in urban areas [14]. $6^{\text {th }}$ Population and Housing Census was conducted in 2017, however, the housing indicators and complete results of the census are not yet available [15].

Housing finance is particularly low in Pakistan, with a mortgage-finance-to-GDP ratio of 0.25 percent which is lowest in South Asia, whereas it is 3 percent in Bangladesh and 11 percent in India [16]. The average annual interest rate in Pakistan is around 10 percent which is high compared to many other countries [17]. Provision of adequate housing is essential for the development of a society. Figure 2 shows a housing paradigm shift model which was adopted in many countries. It emphasizes on provision of housing for all, thermal comfort for all, energy efficiency for all and renewable energy for all. However, it is not encouraged to only focus on the provision of housing and ignoring comfort, energy efficiency and renewable energy.

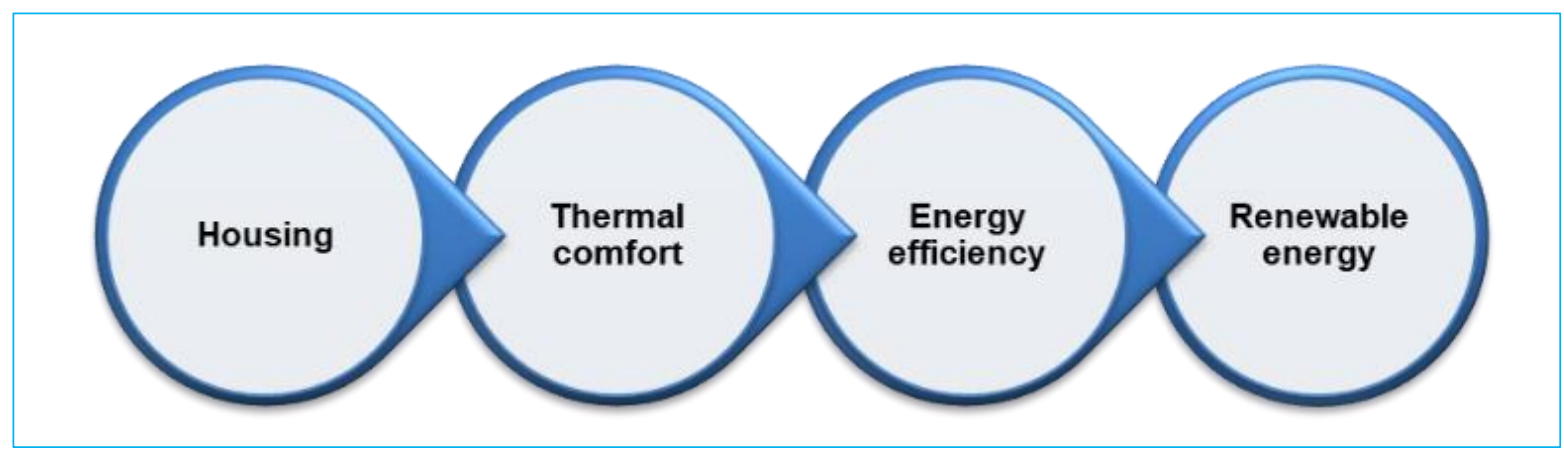

Figure 2. Housing paradigm shift model

Several projects were announced in past by federal, provincial and local governments for the provision of affordable housing. Most of them were either unsuccessful or failed to accomplish the expected goals and targets. Democratic parties and governments put housing as one of their key agenda. Yet, effective steps were not taken, and housing shortage remained a big issue at national level. To date the National Housing Policies are also not properly implemented. Moreover, the current housing policy was made almost 2 decades ago in 2001 [18]. In October 2018, Federal Government of Pakistan announced "Naya Pakistan Housing Program" under the promise of Pakistan 
Tehreek-e-Insaf's General Election 20118 Manifesto to build 5 million houses in next 5 years. The project is initially announced in 7 districts of the country. It is mentioned that the land will be provided by the government and private sector investors will be encouraged to construct the houses. These houses will be provided based on a mortgage scheme with long-term payback period and low interest rates. However, complete details of the project are not yet available. Besides, housing shortage, population growth, rural-urban migration, rapid urbanization, the supply and demand gap of housing and lack of policies and laws also make the provision of housing ineffective.

\subsection{Thermal comfort}

The indoor climate effects the human life, well-being and physical health [19]. During the evaluation of indoor environments, human health and comfort are perceived as the most important parameters [20]. A building must provide comfortable indoor environment and must be energy-efficient. Occupants take alternative measures in uncomfortable situation to get comfort which involves active systems. Use of those active system increases the energy cost and household expenses [21]. The indoor design temperatures mentioned in Building Energy Code of Pakistan (BECP) are $21^{\circ} \mathrm{C}$ in summer and $26^{\circ} \mathrm{C}$ in winter, irrespective of the location of the building across the country [6]. In Building Code of Pakistan (Energy Provisions-2011) these limits are not less than $25^{\circ} \mathrm{C}$ in summer and not more than $22^{\circ} \mathrm{C}$ in winter for a building with HVAC system [7]. Achieving optimal thermal comfort is a big challenge as it depends on several factors including air temperature, radiant temperature, humidity, air velocity, metabolic rate, clothing and the psychology and the condition of an individual. Thermal comfort studies in Pakistan are not very common and were mostly conducted on a small scale or in limited cities. However, in most of the studies it was found that a huge number of the residential buildings in Pakistan do not provided required comfort temperatures to the residents. Using active systems to achieve comfort is very common and people prefer to live in controlled or conditioned spaces [22] [23] [21].

\subsection{Energy efficiency and conservation}

ENERCON identified several potential areas for energy efficiency and conservation in buildings. The most important is building envelope, with 40 percent energy conservation potential. In his regard the building envelope consist building type, location, geometry, roofs, walls and windows. The details of potential areas for energy efficiency and conservation are given in Table 3.

Table 3. Potential energy conservation areas

\begin{tabular}{cc}
\hline Conservation areas & Saving potential \\
\hline Building envelope & $40 \%$ \\
Overall lighting & $29 \%$ \\
High efficiency lighting (LEDs) & $72 \%$ \\
Fluorescent tube light & $83 \%$ \\
Lamp fixtures or luminaries & $50 \%$ \\
Air conditioner & $18 \%$ \\
Printer & $19 \%$ \\
Heaters & $17 \%$ \\
Copier & $10 \%$ \\
Fan & $5 \%$ \\
Computer & $2 \%$ \\
\hline
\end{tabular}

Source: ENERCON 2013

The HVAC systems in the housing consumes more energy specially in the extreme weather, and then the lighting, refrigeration and water heating. The amount of energy used for laundry, cooking or running several electronic items is comparatively low [24]. Energy consumption of a building not only depends on its design, geometry, materials and specification but also depends on climate, location as well as the behaviour and lifestyle of the users. For example, buildings located in the Southern Pakistan, such as Multan, Sukkur and Benazirabad might need more cooling whereas 
$5^{\text {th }}$ International Conference on Energy, Environment \& Sustainable Development (EESD) 2018

Mehran University of Engineering \& Technology (MUET) Jamshoro, Pakistan

Author's Post Print

buildings located in Northern Pakistan might need more heating. However, there are cities where both heating and cooling is required due to the high seasonal variations and extreme temperatures such as in Quetta, Balochistan.

The household's energy consumption in Pakistan is mainly increased by the increased number of users and the expansion of the electricity network to many areas [25]. Advancement in technology and rise in income level tend to increase the ownership of the number of electric and electronic household appliances which also increases the energy consumption of a household [26]. The Government of Pakistan initiated some efforts to reduce the household electricity consumption one of them was a campaign, "free distribution of Compact Fluorescent Lamps (CFLs)" to replace the Incandescent Bulbs (IBs). The prices of CFLs were also reduced to expedite their use in the domestic sector. Using fans for ventilation is very common across the country. Pakistan produces around 8 million fans annually and the fan manufacturing sector employs thousands of workers. There are 250 fan manufacturers in Pakistan and 99 percent of them are located in the province of Punjab. In recent years, the public and private sector together with The World Bank worked to introduce and promote energy efficient fans. Pakistan Energy Label (PEL) for the Fan Industry was created which is a certification for the energy saving fans. By 2017, 13 industries started to produce energy labelled fans. There are 60 million fans installed in Punjab by turning them to energy saving fans which consumes 40 percent less energy, there is potential to save large amount of energy [27].

\subsection{Renewable Energy}

The use of renewable energy in Pakistan is very low compared to the existing potential for the renewable energy in Pakistan [28] [29]. The total energy produced on renewables sources during Jul '17-Feb '18 was only 2 percent while it was zero percent during the same period in 2012-13. In last five years, eighteen wind power projects which the overall capacity of 937.27 MW became operational and started supplying electricity to national grid, whereas six solar power projects of $418 \mathrm{MW}$ capacity also became operational. Six sugar mills installed biogas power generation projects having the cumulative capacity of 201.1 MW which are operational. The Alternative Energy Development Board (AEDB), Energy Ministries at national and provincial level and private sector organizations started projects in rural areas of Sindh, Balochistan and in some other areas of country, providing solar PV to fulfill the energy demands of rural houses. In many areas, tube wells used for irrigation are converted on solar system and several water filtration plants are also being operated on solar energy.

\section{Conclusion}

Habitats evolved over the history to cater human needs and provide them better living conditions. The concept of habitat in today's life is not only the provision of a shelter but to also offer better living conditions, comfort and services of modern life. Climate conditions cannot be ignored while designing residential buildings. In today's life comfort has taken more importance. On the other hand, achieving comfort for long hours and acceptable comfort temperatures for most of the inhabitants is a big challenge. Due to climate change, the global temperature is increasing and several countries including Pakistan will mainly suffer from the situation. Using electricity became part of our everyday life while energy shortage and increasing fuel prices are putting extra burden on the consumers. Many of us live in inefficient and poorly designed houses and using active cooling and heating systems. These systems are expensive, need more energy and increase the overall energy costs which can be reduced by taking alternative measure, design interventions, changing building materials or using insulation etc. Pakistan is a young nation where 64 percent of the population is below the age of 30, and 20 percent is between the ages of 15-29 [30]. Comfort is a basic need of a nation dominated by youth, since comfortable environment provides healthy environment and increases the productivity.

Pakistan produces a major part of its energy from fossil fuels which are imported from other countries. With energy efficiency and conservation, a good sum of energy can be saved which will bring long term economic and environmental benefits. Since the independence of Pakistan, the country went through several changes. Many elected governments failed to complete their period and the nation witnessed long rule of dictators. Political instability created several problems and discontinuity of the policies. Bad governance, corruption and mismanagement made the situation worst in many sectors and profitable government entities went under the debt or crippled. Elected governments also discontinued projects and plans of their predecessors which resulted the wastage of a huge amount of public money without transferring results or benefits to the public. 
The energy efficiency and conservation policies in Pakistan mainly focus on commercial buildings. Single family or multifamily houses are not the focus of existing policy. It is mentioned earlier that household sector is the major consumer of electricity in Pakistan. By reducing energy consumption at household level, a huge amount of energy can be saved. In recent years, private sector introduced several building materials for energy efficiency, renovation and reduction of solar heat gain from roof, walls, floor and to insulate the building envelope. However, the technical and practical efficiency of many available materials is not validated. Many of the houses are still built without the advice of a qualified designer which is creating stock of poorly designed, inefficient and uncomfortable buildings. There is a strong need to formulate better and long-term energy efficiency and conservation policy for the residential sector in Pakistan by involving all stakeholders and qualified professional. Trainings, education and skill development at various levels is also necessary for better implementation and enforcement the policies. By using renewable energy technologies power demand of many households can be met in several parts of the country which will reduce their dependency on the national grid. Many households in Pakistan can afford renewable energy technologies such as solar PV, they need awareness and guidance to fulfil their power needs by using sustainable energy sources.

\section{Acknowledgements}

The authors are grateful to the Higher Education Commission (HEC), Pakistan for providing necessary funds and resources. We are also thankful to Engr. Asad Mahmood, Manager Technical, National Energy Efficiency and Conservation Authority (NEECA) for providing necessary data. We would also like to acknowledge Sustainable Building Design (SBD) Lab, University of Liege, Belgium for providing valuable help and support for this study.

\section{References}

[1] "World Bank Population Growth Data," 2017. [Online]. Available: https://data.worldbank.org/indicator/SP.POP.GROW?locations=PK. [Accessed: 04-Oct-2018].

[2] M. Kugelman, "Urbanisation in Pakistan: Causes and Consequences." Norwegian Peacebuilding Resource Centre, 2013.

[3] "Pakistan Economic Survey 2017-18." Ministry of Finance, Government of Pakistan, 2018.

[4] W. A. Mahar, E. Knapen, and G. Verbeeck, "Methodology to determine housing characteristics in less developed areas in developing countries: A case study of Quetta, Pakistan," presented at the European Network for Housing Research (ENHR) Annual Conference 2017, Tirana, Albania, 2017.

[5] W. A. Mahar and S. Attia, "An overview of housing conditions, characteristics and existing infrastructure of energy, water \& waste systems in Quetta, Pakistan," Sustainable Building Design (SBD) Lab, University of Liège, Belgium, Apr. 2018.

[6] "Building Energy Code of Pakistan." The National Energy Conservation Centre, Environmental \& Urban Affairs Division, Ministry of Housing \& Works, Government of Pakistan, 1990.

[7] "Building Code of Pakistan (Energy Provisions-2011)." Pakistan Engineering Council (PEC) \& National Energy Conservation Centre (ENERCON), Ministry of Housing \& Works, Pakistan, 2011.

[8] "Punjab Energy Efficiency and Conservation Agency." 2017.

[9] Z. K. Kasi, W. A. Mahar, and J. F. Khan, "Structural Defects in Residential Buildings: A Study of Quetta, Pakistan," presented at the 1st International Conference on Advances in Engineering \& Technology (ICAET 2018), BUITEMS Quetta, Pakistan, 2018.

[10] W. A. Mahar, "Defects on Building Facades in Desa Bakti Employee Housing, Universiti Teknologi Malaysia, Skudai, Johor, Malaysia,” Universiti Teknologi Malaysia, Skudai Johor, Malaysia, 2012.

[11] "Final Report: Diagnostic Survey of Housing Finance in Pakistan. Submitted to the State Bank of Pakistan." World bank, 2015.

[12] "Housing inequality in Pakistan: The case of affordable housing." International Growth Centre, 2016.

[13] "Population \& Housing Census." Pakistan Bureau of Statistics (PBS), Government of Pakistan, 1998.

[14] "National Report of Pakistan for HABITAT III.” Ministry of Climate Change, Government of Pakistan, 2015.

[15] "Population \& Housing Census." Pakistan Bureau of Statistics (PBS), Government of Pakistan, 2017.

[16] "International Financial Statistics (IFS).” International Monetary Fund (IMF), 2015. 
[17] "Pakistan Housing Finance Project." The World Bank, 2017.

[18] "National Housing Policy." Ministry of Housing \& Works, Government of Pakistan, 2001.

[19] G. R. Roshan, M. Farrokhzad, and S. Attia, "Defining thermal comfort boundaries for heating and cooling demand estimation in Iran's urban settlements," Building and Environment, vol. 121, pp. 168-189, 2017.

[20] L. Jingxia, "The bioclimatic features of vernacular architecture in China," Renewable Energy, vol. 8, no. 1-4, pp. 305-308, 1996.

[21] W. A. Mahar, M. Amer, and S. Attia, "Indoor thermal comfort assessment of residential building stock in Quetta, Pakistan," presented at the European Network for Housing Research (ENHR) Annual Conference 2018, Uppsala, Sweden, 2018.

[22] F. Nicol and S. Roaf, "Pioneering new indoor temperature standards: The Pakistan project," Energy and Buildings, vol. 23, no. 3, pp. 169-174, 1996.

[23] J. F. Nicol, I. A. Raja, A. Allaudin, and G. N. Jamy, "Climatic variations in comfortable temperatures: the Pakistan projects," Energy and Buildings, vol. 30, no. 3, pp. 261-279, 1999.

[24] A. Sohail and M. ud D. Qureshi, "Energy efficient Buildings in Pakistan," Science Vision: A scientific journal of COMSATS, vol. 16 and 17, pp. 27-37, 2011.

[25] "Pakistan Economic Survey 2014-15." Ministry pf Finance, Government of Pakistan, 2016.

[26] M. A. Mcneil and V. E. Letschert, "Forecasting electricity demand in developing countries: A study of household income and appliance ownership," presented at the European Council for an Energy Efficient Economy (ECEEE), Mandelieu-La Napoule, France, 2005.

[27] "Creating Markets for Energy Efficient Fans in Pakistan." The World Bank, 2017.

[28] "NREL," National Renewable Energy Laboratory, 2007a. [Online]. Available: https://www.nrel.gov/international/images/pak_10km_dni_ann.jpg. [Accessed: 03-Sep-2018].

[29] "NREL," National Renewable Energy Laboratory, 2007b. [Online]. Available: https://www.nrel.gov/international/pdfs/pak_wind.pdf. [Accessed: 03-Sep-2018].

[30] "Pakistan Human Development Index Report." The World Bank, 2017. 